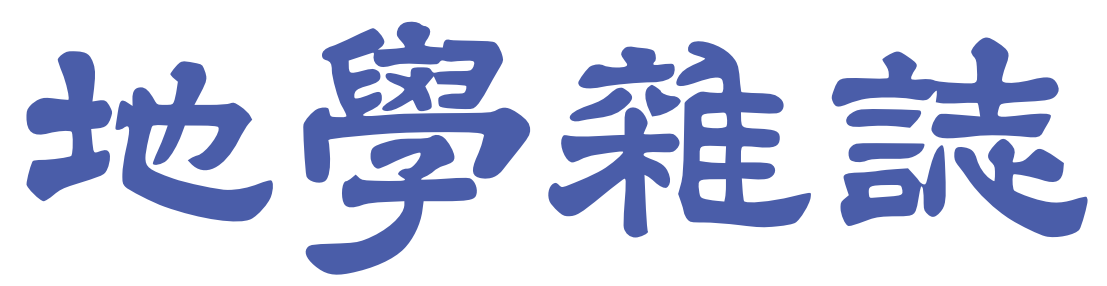

\title{
JOURRAL OF GEOGRAPHY
}

\section{東京地学協会 \\ TOKYO GEOGRAPHICAL SOCIETY \\ Founded in 1879}

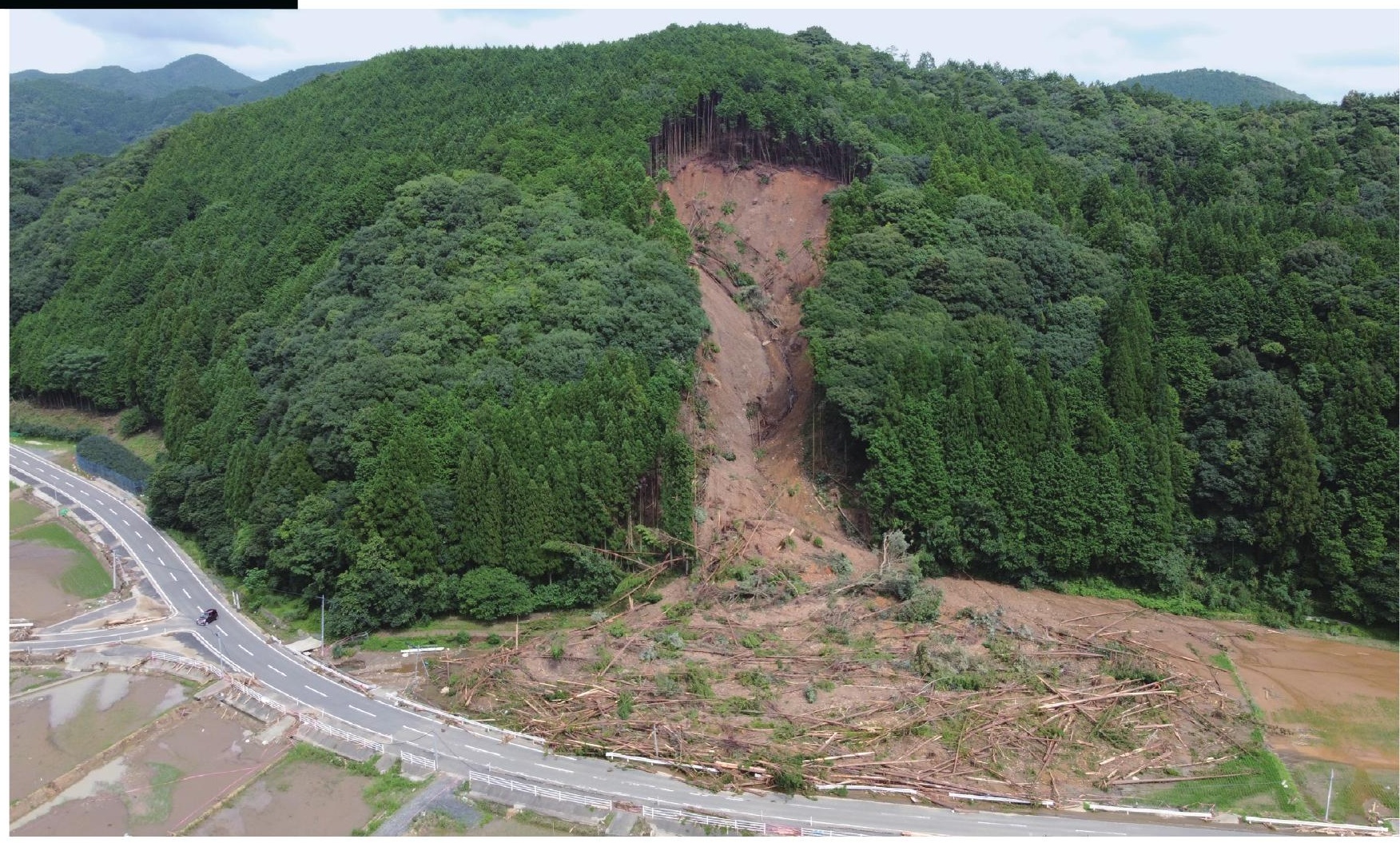

2020 VOL. 129

NO. 5

小特集：富士山の地下水（その 2)

Special Issue : Groundwater in Mt. Fuji (Part 2) 


\section{表紙写真}

\section{令和 2 年（2020 年） 7 月豪雨によって熊本県南部で発生した斜面崩壊}

2020 年 7 月 3 日から 4 日に記録的な豪雨に見舞われた熊本県南部の芦北町と津奈木町では多数の斜面災害や浸水被 害等が発生し，14 名の貴重な人命が奪われた．今回の斜面災害はジュラ紀の付加体が分布する地域を中心に起こってお り，土石流に移行したものとそうでないものが認められた。いずれの夕イプの崩壊も厚い風化土層内で発生したもので あり, 深さが $20 \mathrm{~m}$ 程度に達するものはあるが, 岩盤が大きく破壊されるような深層崩壊ではなかった。写真は芦北町 宮浦地区の傾斜 $30^{\circ}$ 程度の浅い凹型の林地斜面で起こった高さ $70 \mathrm{~m}$, 幅 $40 \mathrm{~m}$ 程度の崩壊を撮影したものである. 滑落 崖には赤褐色の厚い風化土層が見え, 崩壊下部の狭窄部では断層破砕带も観察された。この崩壊では多量の土砂と流木 が発生したが，その流下堆積域に住宅などの建物がなかったため，人的被害は出ていない.

(写真・解説 : 宮縁育夫 2020 年 7 月 12 日撮影)

\section{Landslide Caused by the July 2020 Torrential Rain in the Southern Part of Kumamoto Prefecture}

Intense rainfall related to a stationary front on July 3-4, 2020 triggered many landslides and floods in the southern part of Kumamoto Prefecture, Kyushu, southwestern Japan. The July 4, 2020 landslides were concentrated mainly in Ashikita and Tsunagi towns along the Yatsushiro Sea, resulting in severe damage to houses and twelve fatalities. The landslides occurred mainly in areas underlain by Jurassic accretionary complexes of the Chichibu Belt, with some of them occurring on steep upper slopes along valleys mobilized into debris flows, which traveled along stream channels and flooded the lower reaches. Most of the landslides occurred in thick weathered soil layers overlying bedrock; the slides were generally less than $20 \mathrm{~m}$ thick. The photograph shows a landslide that occurred on a $30^{\circ}$ forested slope at Miyanoura (Ashikita town). The height and width of the landslide were $70 \mathrm{~m}$ and $40 \mathrm{~m}$, respectively. A thick reddish soil layer can be seen at the head scarp, and a fault fracture zone is observed at the lower part of the landslide. Although the landslide produced large amounts of sediments and woody debris, there were no houses in the transported and depositional zone. 